\title{
Effect of Maturation Degree of Areca Nut and Binder Treatment to The Physicochemical Properties and Citotoxicity of Spray-dried Areca Nut (Areca catechu L) Extracted Powder
}

\author{
Yernisa", E. Gumbira-Said*, Khaswar Syamsu* \\ \# Agricultural Engineering and Technology Faculty, Jambi University, Jambi Province 36364, Indonesia \\ E-mail:yernisa@gmail.com
}

* Department of Agroindustrial Technology, Faculty of Agricultural Engineering and Technology, Bogor Agricultural University, Indonesia E-mail: khaswars@yahoo.com

\begin{abstract}
Areca nut (Areca catechu $\mathbf{L}$ ) is a rich polyphenol source which is potential health-benefit. Polyphenol could extract from the sources and then converted to solid powder by spray drying. Polyphenol powder is easy to use and to introduce it into food (materials). The objective of this study was to determine the effect of maturation degree of areca nut (unripe, ripe) and binder treatment (without a binder, arabic gum $2 \% \mathrm{w} / \mathrm{v}$ ) on the physicochemical properties and citotoxicity of spray-dried areca nut extracted powder. This study used a completely randomized design (CRD). Data were analysed statistically used an analysis of variance. Analysis of the results exhibited unripe areca nut produced powder with higher in yield, moisture content and total phenolic content but had no significant effect on $\mathrm{pH}$ and lower in bulk density and solubility than ripe areca nut. Arabic gum treatment produced powders with higher in yield, and solubility, but had no significant effect on moisture content and lower in bulk density, pH and total phenolic content than the treatment without binder. The areca nut extracted powders from all combination of treatments exhibited high cytotoxic activity against brine shrimp larvae with LC50 less than 1000 ppm, excepted the powders from ripe areca nut with arabic gum.
\end{abstract}

Keywords - Areca nut, spray drying, polyphenol, brine shrimp lethality test.

\section{INTRODUCTION}

Areca nut is the seed or endosperm (nut) of Areca catechu Linn. Areca nut is one of commercial commodities in the world. Areca nut has been known as traditional medicines and various pharmacological activities have been found in the areca nut extract. It related with active compounds in areca nut. The main active compound of areca nut is polyphenol [1]. Polyphenol compounds are used in the foodprocessing industry as natural additives (natural coloring agents, concervative agents, natural antioxidants, nutritional additive) or into cosmetic or pharmaceutical formulations purpose [2].

Group of polyphenol in areca nut is flavonoid and tannin ([1], [3], [4]). Content of total polyphenol depends on maturation degree of fruit. Content of total polyphenol decreases during maturation of fruit [5].

Most of areca nut was purchased in dried nut (whole, half, sliced and ground). For further applications, they should be extracted by certain solvent to obtain polyphenol compounds. Extracted polyphenol could be evaporated into powder that should be done under mild condition (low temperature and short time) to maintain their activity. Spray drying is one of method to get those purpose [2]

Binder is usually used to produce powders in order to maintain bioactive compounds, reduce losses and increase the product yield. Arabic gum is one common of binder that easily dissolves in water and maintain bioactive compounds during drying process [6].

In this study, areca nut was extracted and spray dried to obtain extracted powder. The objective of this study was to determine the effect of maturation degree of areca nut (unripe, ripe) and binder treatment (without a binder, arabic gum $2 \% \mathrm{w} / \mathrm{v}$ ) on the physicochemical properties and citotoxicity of spray-dried areca nut extracted powders. 


\section{MATERIALS AND METHODS}

\section{A. Plant Material}

The fruits of Areca catechu L. unripe (green) and ripe (yellow orangish) were obtained from the province of Jambi, Indonesia. After removing the husks, the nuts were sliced $( \pm$ $2 \mathrm{~mm})$, dried $\left(50^{\circ} \mathrm{C}, 48\right.$ hours $)$ and ground by disc mill (40 mesh) to obtain flour of areca nut (unripe and ripe). Areca nut flour (unripe and ripe) was characterized with proximate analysis [7].

\section{B. Preparation of Areca Nut Extract}

The extraction was based on [8] and also has been used in our previous study [9]. Flour of areca nut (Unripe, ripe) was extracted with water $(1: 10 \mathrm{w} / \mathrm{v})$ in three neck flask with condensor on hot plate magnetic stirrer at $80^{\circ} \mathrm{C}$ for 45 minutes. Filtrates were separated from residues using filter paper on vacuum pump. Total soluble solid of filtrates from unripe and ripe areca nut were measured by refractometer ABBE. Before spray dring, those filtrates were treated with no binder and with arabic gum (Brataco Chemical Bogor) at concentration $2 \%(\mathrm{w} / \mathrm{w})$.

\section{Making Spray-dried Areca Nut Extracted Powders}

Areca nut filtrates were dried into powders using spray drier designed by Team of Gambier Researches, Department of Agro industrial Technology, Bogor Agricultural University [10]. The inlet air temperature was $130^{\circ} \mathrm{C}$ and outlet temperature was $80^{\circ} \mathrm{C}$. This condition also has been used in our previous study [9]. The physicochemical properties of the powders measured were yield, moisture content [7], bulk density [11], solubility, $\mathrm{pH}$ (using $\mathrm{pH}$ meter), total phenolic content [7] and ${ }^{\circ}$ Hue [12]. The citotoxicity was analyzed using Brine Shrimp Lethality Test [13].

\section{Research Design}

This study designed used a completely randomized design with two treatments. The treatments were maturation degree (unripe; ripe) and binder treatment (without binder; arabic gum). All experiments were conducted in duplicate and analysed statistically used an analysis of variance.

\section{RESULTS AND DISCUSSION}

\section{A. Characteristics of Areca Nut Flours and Filtrates}

Flour of unripe and ripe areca nuts that were used in this study, were characterized by proximate analysis (Table I).

TABLE I

CHEMICAL Compounds UnRIPE ANd RIPE ARECA Nut Flour

\begin{tabular}{|l|c|c|}
\hline Component & $\begin{array}{c}\text { Unripe Areca } \\
\text { Nut Flour }\end{array}$ & $\begin{array}{c}\text { Ripe Areca } \\
\text { Nut Flour }\end{array}$ \\
\hline Water $(\% \mathrm{wb})$ & 6.28 & 5.53 \\
\hline Protein $(\% \mathrm{db})$ & 5.36 & 3.96 \\
\hline Lipid $(\% \mathrm{db})$ & 15.99 & 16.48 \\
\hline Ash $(\% \mathrm{db})$ & 1.81 & 1.73 \\
\hline Crude Fibre $(\% \mathrm{db})$ & 10.34 & 12.25 \\
\hline Carbohidrat $($ by diff. $)(\% \mathrm{db})$ & 60.22 & 60.05 \\
\hline
\end{tabular}

$\mathrm{wb}=$ wet basis; $\mathrm{db}=$ dry basis
Areca nuts were formed into flour or ground in order to make materials were extracted easily. Water content of areca nut was reduced until less than $7 \%$. So, materials were handling easier and can used anytime .

Filtrates or extracts of areca nut which have not treated yet were also characterized. Based on visual observation, color of unripe areca nut filtrates was more dark than ripe areca nut filtrates. The differences in filtrate color showed the differences of amount of components were extracted. Total soluble solid of areca nut extracts (unripe and ripe) shown in Table II.

TABLE II

Total Soluble Solid Of UnRIPE AND RIPE ARECA Nut Filtrates

\begin{tabular}{|l|c|}
\hline Material & Total Soluble Solid $\left({ }^{\mathbf{0}}\right.$ Brix) \\
\hline Unripe areca nut filtrate & 2.60 \\
\hline Ripe areca nut filtrate & 1.75 \\
\hline
\end{tabular}

Table II showed that total solule solid of unripe areca nut filtrate was higher than ripe. Total soluble solid of feed would effect yield of products. Higher total soluble solid of feed would higher yield of products.

\section{B. The Physicochemical Properties of Spray-Dried Areca Nut Extracted Powders}

The physicochemical properties are important for designing products, analysing behaviour of products and determining suitable process to manufacture products.

1) Yield: Yield showed amount of areca nut extracted powders that was produced from areca nut with or without binder by spray drier that expressed in percent. Production yield of spray-dried areca nut extracted powders varied from $5.59 \%$ to $13.0 \%$ (wet basis) (Fig. 1). Maturation degree and binder treatment had significant effect to yield of powders and there were no interaction on both of them. Unripe areca nut produced higher yield of powders than ripe. Higher yield at unripe areca nut related with amount of components that extracted from areca nut flour. It expressed on total soluble solid, which Table II showed unripe areca nut total soluble solid was higher than ripe ones.

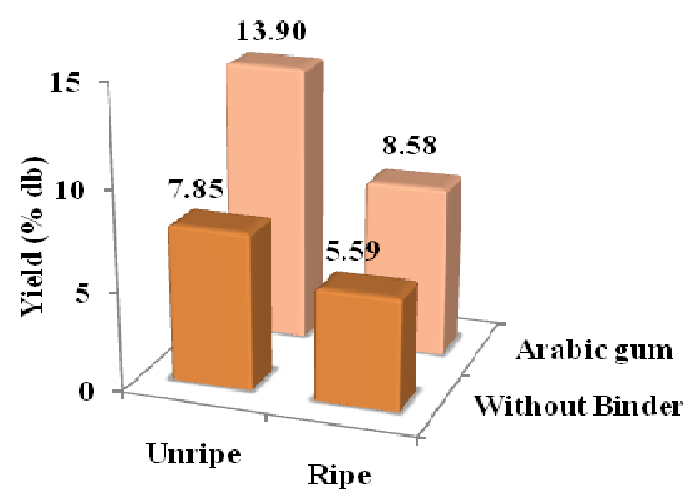

Fig 1. Effect of maturation degree and binder treatment on yield of spraydried areca nut extracted powder.

Arabic gum treatment produced yield of powders higher than without binder. Spray drying with binder can reduce the losses of the powders because of binder ability to bind active compound. Materials could adhere to the wall chamber and 
cyclone if the feeds were not use binder as reported [14] and [15].

2) Moisture Content: Moisture content is important parameter for powder because of it could effect stability and powder storage. The moisture content of spray-dried areca nut extracted powders varied from $5.19 \%$ to $7.41 \%$ (Fig. 2). It showed all of powders that were produced in this study had water content less than $10 \%$ as in range of powders water content globally.

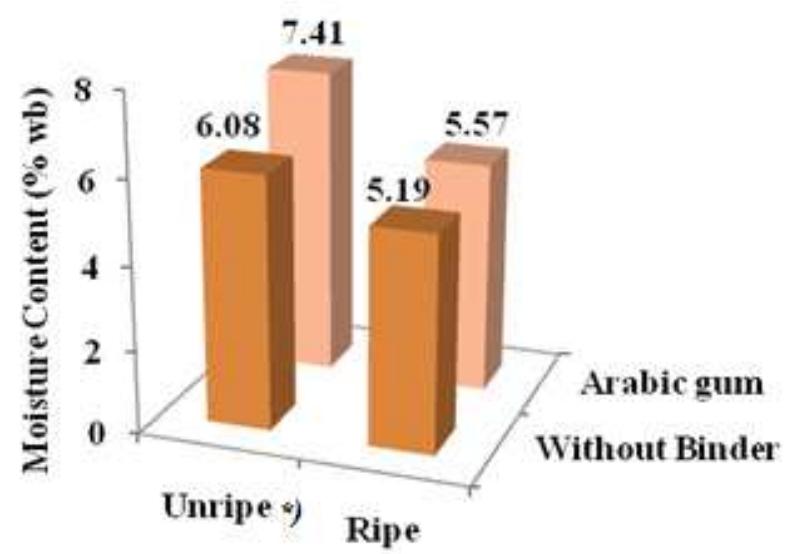

Fig 2. Effect of maturation degree and binder treatment on moisture content of spray-dried areca nut extracted powders [22].

Analysis of variance showed maturation degree gave significant effect on moisture content of spray-dried areca nut extracted powders but binder treatment and interaction both of treatment did not give significant effect. Unripe areca nut produced higher moisture content of powders than ripe ones.

3) Bulk Density: Bulk density is rasio of product weight at certain volume. It determine bulky of products. The product was bulky when its bulk density was low. Bulk density is need to package handling, space of transportation and distribution and space for products storages.

Bulk density of spray-dried areca nut extracted powders varied from $0.3720 \mathrm{~g} / \mathrm{ml}$ to $0.5586 \mathrm{~g} / \mathrm{ml}$ (Fig 3). Analysis of variance showed maturation degree had significant effect and binder treatment and interaction of treatment gave stongly significant effect on bulk density of spray-dried areca nut extracted powders.

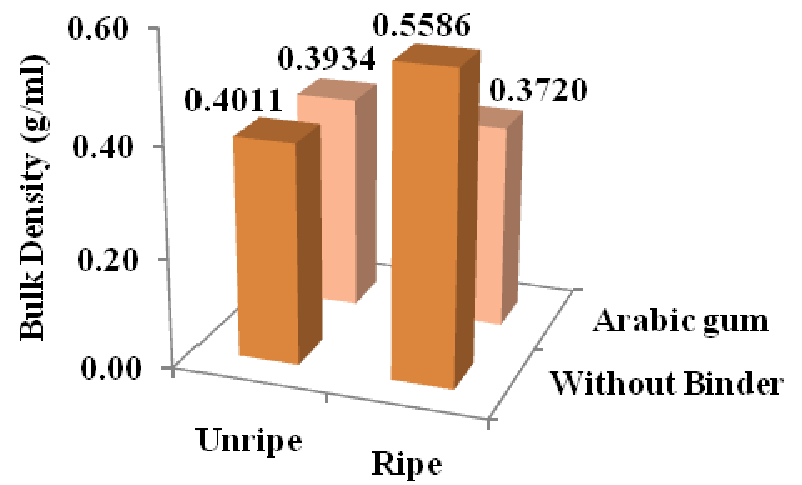

Fig 3. Effect of maturation degree and binder treatment on bulk density of spray-dried areca nut extracted powders.

Ripe areca nut produced higher bulk density powders than unripe and arabic gum treatment produced lower bulk density powders than without binder. Using Arabic gum was reduced bulk density of spray-dried areca nut extracted powders. Reference [6] reported that arabic gum had ability film forming as an encapsulation agent became a wall of targeted active compound (core) in spray drying. Reference [16] reported the presence of encapsulation agent reduced stickiness of inter-particles and air could be trapped in particles. Air trapped caused increasing volume of powders, so bulk density powders reduced.

4) Solubility: Solubility showed amount of product could be dissolve in certain solvent. Solubility is one of important powder parameter because it related with eficiency of products. Solubility of powders should be high in certain solvent cause it can easy application and saving time and energy. In this study, solubility was measured by dissolving powders into water (aquadest) in room temperature. Analysis of variance showed maturation degree and binder treatment had significant effect on solubility of spray-dried areca nut extracted powders but there were no interaction on both of factor of treatment.

Solubility of spray-dried areca nut extracted powders varied from $94.10 \%$ to $99.25 \%$ (Fig. 4). This ranges of solubility showed that powders had high solubility in water. It was caused active compound of areca nut extracts and binder dissolve easily in water. Reference [17] stated fenolic compound (tannin and flavonoid) was soluble in water. Arabic gum as a binder of areca nut extracts could increase powders solubility in water. Reference [18] stated arabic gum is one of binder mostly used in spray drying because of its solubility in water was high.

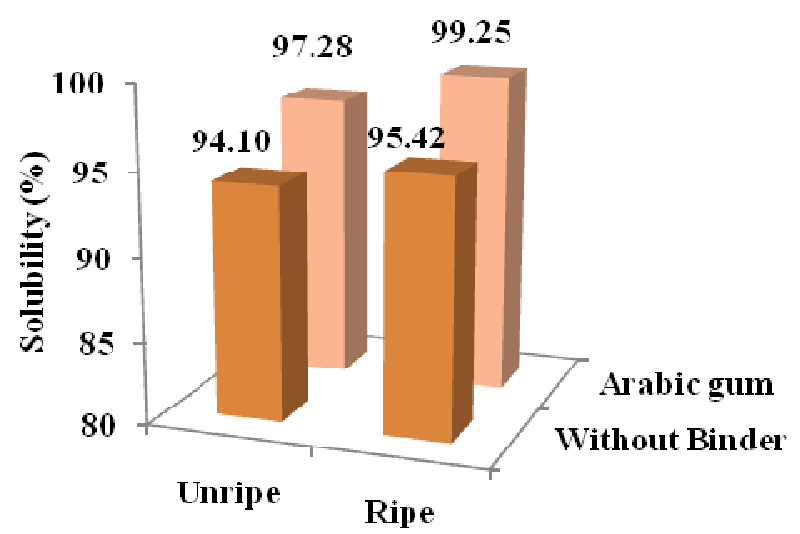

Fig 4. Effect of maturation degree and binder treatment on solubility of spray-dried areca nut extracted powders.

5) $\mathrm{pH}: \mathrm{pH}$ of spray-dried areca nut extracted powders (solute in water) varied from 4.98 to 5.28 (Fig. 5). Analysis of variance showed maturation degree and interaction of both of treatment had no significant effect on $\mathrm{pH}$ spray-dried areca nut extracted powders but binder treatment gave significant effect. $\mathrm{pH}$ of powders with Arabic gum were higher than without binder. Arabic gum is slightly acid ( $\mathrm{pH}$ 5.0).

6) Total Phenolic Content: Total phenolic content of spray-dried areca nut extracted powders varied from $31.65 \%$ to $67.07 \%$ (Fig. 4). Analysis of variance showed maturation degree, binder treatment and interaction had significant effect on total phenolic content of spray-dried areca nut 
extracted powders. Unripe areca nut produced higher total phenolic content powders than ripe areca nut. Reference [5] stated polyphenol content decreased during maturation of fruit. Increasing polimerization degree of tannin or polyphenol happened during maturation of fruit, so decreasing tannin could be extracted.

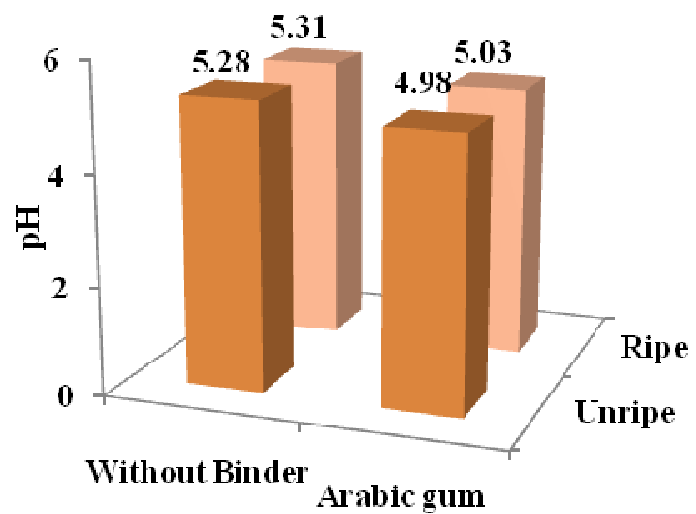

Fig 5. Effect of maturation degree and binder treatment on bulk density of spray-dried areca nut extracted powders.

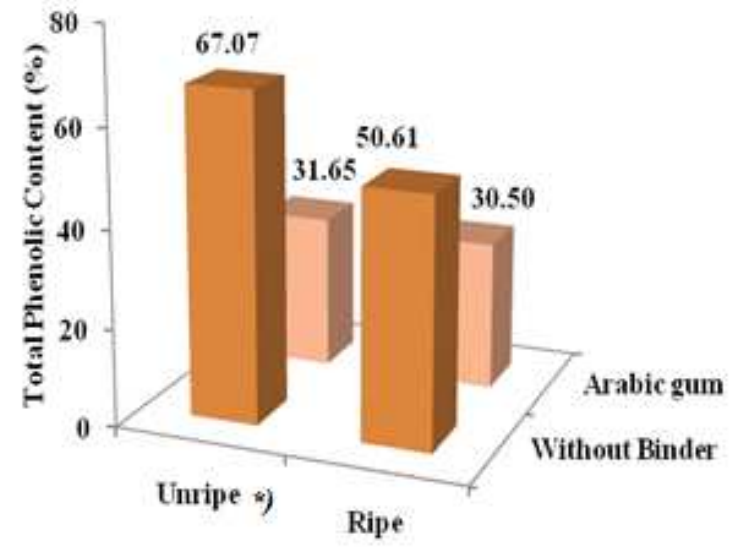

Fig 6. Effect of maturation degree and binder treatment on total phenolic content of spray-dried areca nut extracted powders [22]

7) ${ }^{o}$ Hue (Color): ${ }^{\circ}$ Hue and color spray-dried areca nut extracted powders from all treatment were presented in Table III. ${ }^{\circ}$ Hue varied from 39.7 to 60.49 . Base on those ranges, almost all of treatment exhibited powders in yellow red color, except powders made from ripe areca nut without binder.

TABLE III

${ }^{\circ}$ HUE AND COLOR OF SPRAY-DRIED ARECA NUT EXTRACTED POWDERS MADE FROM DIFFERENT MATURATION DEGREE OF ARECA NUT AND BINDER TREATMENT

\begin{tabular}{|l|l|l|}
\hline \multicolumn{1}{|c|}{ Treatments } & ${ }^{\mathbf{0}}$ Hue & \multicolumn{1}{c|}{ Color } \\
\hline Unripe, without binder [22] & 59.70 & Yellow red \\
\hline Unripe, arabic gum [22] & 60.49 & Yellow red \\
\hline Ripe, without binder & 39.67 & Red \\
\hline Ripe, arabic gum & 62.06 & Yellow red \\
\hline
\end{tabular}

\section{Citotoxicity of Spray-Dried Areca Nut Extracted Powders}

Citotoxicity of spray-dried areca nut extracted powders was analized by Brine Shrimp Lethality Test (BSLT). BSLT is a method to count responses of $50 \%$ mortality of Artemia salina Leach that expressed in Lethal Concentration $\left(\mathrm{LC}_{50}\right)$ value. It was calculated by determining the total death and percentage mortality (death) at different concentration of extract or sample and control then find the equation by linear regression. LC $_{50}$ expressed toxicity of materials. BSLT determined bioactivity of materials. Toxicity of material was determined by containing bioactive compounds in it. There were positive correlation between toxicity (BSLT) and citotoxicity at culture of cancer cells. Materials had anti cancer bioactive which had $\mathrm{LC}_{50}$ less that $1.000 \mathrm{ppm}$ [13].

Citotoxicity of spray-dried areca nut extracted powders varied from $279.53 \mathrm{ppm}$ to $10,935.21 \mathrm{ppm}$ (Table IV).. LC $_{50}$ of powders from unripe areca nut with arabic gum or without binder were less than $1,000 \mathrm{ppm}$ and so did ripe areca nut without binder. Only $\mathrm{LC}_{50}$ powder from ripe areca nut without arabic gum which were more than 1,000 ppm. So, spray-dried areca nut extracted powders were potential as sources of anti cancer bioactive compounds. Reference [19] reported phenolic compounds of areca nut etanolic extracts (25-100 $\mu \mathrm{g} / \mathrm{mL})$ could inhibite $13-84 \%$ growth of breast cancer cell , MCF-7. Beside that, areca nut had anti bacteria activity to inhibite bacteria of gram positive or negative [20], anti radical activity and antioxidant ([21], [22]). Its indicated that spray-dried areca nut extracted powders might have functional properties for wide application like food, cosmetics or medicines.

TABLE IV

CITOTOXICITY OF SPRAY-DRIED ARECANUT EXTRACTED POWDERS MADE FROM DIFFERENT MATURATION DEGREE OF ARECA NUT AND BINDER TREATMENT

\begin{tabular}{|l|c|}
\hline Treatments & LC $_{\mathbf{5 0}}$ (ppm) \\
\hline Unripe, without binder & 279.53 \\
\hline Unripe, arabic gum & 508.81 \\
\hline Ripe, without binder & 446.93 \\
\hline Ripe, arabic gum & $10,935.21$ \\
\hline
\end{tabular}

\section{CONCLUSIONS}

Maturation degree had significant effect on yield and almost all of physicochemical properties like moisture content, bulk density, solubility and total phenolic content, except $\mathrm{pH}$. Unripe areca nut produced spray-dried powders with higher in yield, moisture content and total phenolic content, but had no significant effect on $\mathrm{pH}$ and lower in bulk density and solubility than ripe areca nut. Binder treatment had significant effect on yield and also almost all of physicochemical properties except moisture content. Arabic gum treatment produced powders with higher in yield, and solubility, but had no significant effect on moisture content and lower in bulk density, $\mathrm{pH}$ and total phenolic content than the treatment without binder. The areca nut extracted powders from all combination of treatments exhibited high cytotoxic activity against brine shrimp larvae with $\mathrm{LC}_{50}$ less than $1000 \mathrm{ppm}$ excepted the powders from ripe areca nut with arabic gum.

\section{REFERENCES}

[1] M.S. Amudhan, V.H. Begum, and K.B. Hebbar, "A review on phytochemical and pharmacological potential of Areca catechu L," Int. J. Pharm. Sci Res., vol 3, No. 11, pp. 4151-4157, 2012.

[2] A. Munin and F. Edwards-Levy, ." Encapsulation of natural polyphenolic compounds: a review," Pharmaceutics, vol. 3, pp. 793829, 2011.

[3] Y. Ma, F. Hsu, S.J. Lan, and C. Chen, "Tannins from betel nuts," J. of the Chinese Chem. Soc., vol. 43, pp. 77-81, 1996. 
[4] G.I. Nonaka, "Isolation and structure elucidation of tannins," Pure \& Appl. Chem., vol. 61, No. 3, pp. 357-360, 1989.

[5] M..S Amudhan, "Changes in polyphenol and arecoline contents in Areca catechu genotypes during maturity," Indian J. Plant Physiol., vol. 15, No. 3, pp. 242-245, 2010.

[6] A. Gharsallaoui, G. Roudaut, O. Ghambin, A. Volley, and R. Saurel, "Application of spray drying in microencapsulation of food ingredients: An overview," Food Res. Int., vol. 40, pp. 1107-1121, 2007.

[7] [AOAC] Association of Official Analytical Chemists, Official Method of Analysis of Association Official Analytical Chemists, Washington: AOAC International, 2005.

[8] C. Sardsaengjun and A. Jutiviboonsuk, " Effect of temperature and duration time on polyphenol extract of Areca catechu Linn seeds, "Thai. Pharm. Health Scie. J., vol. 5. No. 1, pp. 14-17.

[9] Yernisa, E. Gumbira-Said, K. Syamsu, "Aplikasi pewarna bubuk alami dari ekstrak biji pinang (Areca catechu L.) pada pewarnaan sabun transparan,” J. Tek. Ind. Pert., vol. 23, No. 3, pp. 190-198, 2013

[10] E. Gumbira-Sa'id, K. Syamsu, E. Mardliyati, A.H. Brontoadie, and N.A. Evalia, "Perbaikan rekayasa proses, pengembangan produk dan peningkatan mutu gambir ekspor Indonesia: pendalaman studi kasus di Kabupaten Lima Puluh Kota, Propinsi Sumatera Barat", Laporan Penelitian Hibah Unggulan Strategis Nasional, Institut Pertanian Bogor, Bogor, 2009.

[11] A.M. Goula, T.D. Karapantsios, D.S. Achilias, and K.G. Adamopoulos, "Water sorption isotherms and glass transition temperature of spray dried tomato pulp", J. Food Eng., vol. 85, pp. 73-83, 2008.

[12] J.B. Hutching, "Food Color and Appearace," 2nd Ed., Maryland: Aspen Publ. Inc., 1999.

[13] B.N. Meyer, N.R. Ferrigni, J.E. Putnam, L.B. Jacobsen, D.E Nichols and J.L. McLaughlin., "Brine Shrimp: A Convenient General Bioassay for Active Plant Constituents," Planta Medica, vol. 45, pp. 31-34, 1982
[14] S. Yousefi, Z. Emam-Djomeh, and S.M. Mousavi. "Effect of carrier type and spray drying on the physicochemical properties of powdered and reconstituted pomegranate juice (Punica Granatum L.)," J. Food Sci. Technol., vol. 48, No. 6, pp. 677-684, Nov-Des 2011.

[15] K. Sarabandi, S.H. Peighambardoust and M. Shirmohammadi, "Physical properties of spray dried grape syrup as affected by drying temperature and drying aids," Int. J. Agric. Crop Sci., vol. 7, No. 12, pp. 928-934, 2014.

[16] A.M. Goula and K.G. Adamopoulos, "A new technique for spray drying orange juice concentrate. Innovative", Food Sci. Emergig. Technol., vol. 11, pp. 342-351, 2010.

[17] J.B. Harbone, "Metode Fitokimia: Penuntun Cara Modern Menganalisa Tumbuhan" K. Padmawinata dan I. Soediro, penerjemah. Bandung: Penerbit ITB. Terjemahan dari: Phytochemical Methods. 2006.

[18] B.H. Ali, A. Ziada and G. Blunden, "Biological effect of gum arabic: a review of some recent research," Food Chem Toxicol., vol. 47, pp. 1-8, 2009.

[19] E. Meiyanto, R.A. Susidarti S. Handayani, and F. Rahmi, "Ekstrak etanolik biji buah pinang (Areca catechu L.) mampu menghambat proliferasi dan memacu apoptosis sel MCF-7," Majalah Farmasi Indonesia, vol. 19, No. 1, pp. 12-19, 2008.

[20] A. Karphrom, S. Suknaisilp, P. Pradepasaena and S. Tantratian, "Anti-microbial activities betel nut (Areca catechu Linn) seed extracts," Proc. of International Conference on the Role of Universities in Hands-On Education Rajamangala University of Technology Lanna. Chiang-Mai, Thailand, 23-28 Agustus 2009.

[21] C. Li and E. Lin, "Antiradical capacity and reducing power of different extraction method of Areca catechu seed," African .J Biotechnol., vol. 9, No, 46, pp. 7831-7836, 2010.

[22] P. Maisuthisakul, M. Suttajit and R. Pongsawatmanit, "Assessment of phenolic content and free radical-scavenging capacity of some Thai indigenous plants," Food Chem, vol. 100, pp. 1409-1418, 2007. 